\title{
Acclimation of Wax Begonia to Light Intensity: Changes in Photosynthesis, Respiration, and Chlorophyll Concentration
}

\author{
Krishna S. Nemali and Marc W. van Iersel \\ Horticulture Department, 1111 Plant Science Building, The University of Georgia, Athens, \\ GA 30602-7273
}

\begin{abstract}
AdDitional INDEX wORDs. dark respiration rate, light compensation point, light saturation point, net assimilation rate, quantum yield

Aвstract. Physiological acclimation of plants to light has been studied mostly at the leaf level; however whole-plant responses are more relevant in relation to crop growth. To examine the physiological changes associated with different daily light integrals (DLI) during growth of wax begonia (Begonia semperflorens-cultorum Hort.), we grew plants under DLI of 5.3, 9.5, 14.4, and $19.4 \mathrm{~mol} \cdot \mathrm{m}^{-2} \cdot \mathrm{d}^{-1}$ in a whole-plant gas exchange system. Photosynthesis-light response curves of groups of 12 plants were determined after $25 \mathrm{~d}$ of growth. Physiological parameters were estimated per $\mathbf{m}^{2}$ ground area and per $\mathbf{m}^{2}$ leaf area. On a ground area basis, significant increases in dark respiration $\left(\mathbf{R}_{\mathrm{d}}\right)$, quantum yield $(\alpha)$, the light compensation point (LCP), and maximum gross photosynthesis $\left(\mathbf{P}_{\mathrm{g}, \mathrm{max}}\right)$ were seen with increasing DLI. Variations in physiological parameters among different treatments were small when corrected for differences in leaf area. On a leaf area basis, $\alpha$, LCP, and the light saturation point (LSP) did not change significantly, whereas significant increases in $\mathbf{R}_{\mathrm{d}}$ and $\mathbf{P}_{\mathrm{g} \text {,max }}$ were seen with increasing DLI. There was a small decrease in leaf chlorophyll concentration (6.3\%, measured in SPAD units) with increasing DLI. This study indicates that wax begonias acclimate to low DLI by increasing their leaf chlorophyll concentration, presumably to more efficiently capture the available light, and to high DLI by increasing $\mathbf{P}_{\mathrm{g} \text {,max }}$ to efficiently utilize the available light, thereby maximizing carbon gain under both situations.
\end{abstract}

Biomass production, under conditions of nonlimiting water and nutrient supply, is highly correlated with the amount of photosynthetic photon flux $(P P F)$ available to the plants, the fraction of $P P F$ intercepted by the plants, and the efficiency with which the captured $P P F$ is used by the plants (Casella and Ceulemans, 2002). The amount of $P P F$ incident on top of plants can vary greatly depending on their habitat (e.g., under-canopy vs. unshaded habitat). In response to these variations, many species acclimate to the local light regime, allowing them to maximize photosynthesis and growth in different light environments. Acclimation can be defined as a phenotypic (physiological, morphological, or anatomical) change in an organism in response to a change in environmental conditions.

Key mechanisms governing plant performance in varying light environments involve acclimation responses resulting either in increased light capture or improved light utilization. Acclimation responses to shade include higher shoot to root ratio (whole-plant level) and increased leaf area per unit leaf dry mass (individual leaf level) (Allard et al., 1991; Evans and Poorter, 2001; Marenco et al., 2001). Both of these acclimation responses enable plants to produce a larger leaf area. At the cellular level, there may be an increase in the total chlorophyll content and a decrease in the chlorophyll $a / b$ ratio in response to low light conditions (Adams and Demmig-Adams, 1992; Close et al., 2001). Therefore, acclimation responses to shade mainly enable plants to capture a larger fraction of the available light. However, a recent study (Reich et al., 2003), which compared traits associated with shade tolerance in a large number of tropical and temperate species, indicated that most of the shade-tolerant species acclimated to

Received for publication 4 Feb. 2004. Accepted for publication 17 Apr. 2004. We thank Larry Freeman and Keven Calhoun for their technical support and Speedling Inc., Blairsville, Ga., for providing the plant material.

${ }^{1}$ Corresponding author; e-mail mvanier@uga.edu shade by decreasing the respiration rate per unit dry mass (thus preserving carbohydrates), decreasing leaf $\mathrm{N}$ concentration, and prolonged leaf longevity.

In contrast, when grown under high $P P F$, most plants respond by increasing their photosynthetic capacity, thereby utilizing the available $P P F$ more efficiently. Compared to shade-grown leaves, the fraction of $\mathrm{N}$ invested in chlorophyll to that invested in photosynthetic enzymes is lower, resulting in higher amounts of Rubisco and increased photosynthetic rates per unit leaf area (Parry et al., 2003; Warren and Adams, 2001) . It has been shown that higher photosynthetic rates under high $P P F$ are associated with increased $\mathrm{CO}_{2}$ conductance to the carboxylation sites (Piel et al., 2002). Oguchi et al. (2003) have indicated that increased $\mathrm{CO}_{2}$ conductance rates in plants transferred from low to high $P P F$ conditions are due to alignment of chloroplasts along the wall of the mesophyll tissue facing the intercellular spaces.

Photosynthesis-light response curves are commonly used to study the underlying physiology and acclimation of plants subjected to different daily light integrals (DLI) during growth (Baille et al., 1996; Callan and Kennedy, 1995; Funnell et al., 2002; Marenco et al., 2001; Miller et al., 2001). Most light acclimation studies have used single-leaf photosynthesis measurements. However, due to intra-canopy shading, light gradients exist within a canopy, and single-leaf measurements may not be accurate indicators of whole-plant responses. In contrast, wholeplant photosynthesis integrates responses in leaves at different positions within a canopy.

To accurately determine acclimation responses, different light treatments need to be applied for long durations (weeks). This complicates comparisons at the whole-plant level, because plants grown at a high DLI generally will grow faster and have a larger leaf area. Due to this larger leaf area, plants grown under high DLI will intercept more light and thus have higher whole-plant photosynthetic rates than plants grown under low DLI, when 
exposed to the same instantaneous $P P F$. Accounting for differences in leaf area by calculating $\mathrm{CO}_{2}$ exchange rates (CER) per square meter leaf area does not provide a complete solution to this problem. Plants with a large leaf area (high DLI) will have a higher leaf area index, and thus more intra-canopy shading than those grown under low DLI. Therefore, leaves at the bottom of the canopy of plants grown under high DLI likely receive and intercept less PPF than those grown under low DLI with small canopies. This in turn may lead to low photosynthetic rates in the lower leaves of large plants, and thus decreases the average photosynthetic rate per unit leaf area. However, when whole-plant photosynthesis is light-saturated, the shading of lower leaves is no longer a problem, because even those leaves are light-saturated at that point.

Wax begonia is among the most popular bedding plants, and is produced throughout the United States (USDA-NASS, 2003). Light requirements of wax begonias (a shade-tolerant bedding plant) are poorly understood, and wax begonias seem to perform well under a wide range of light intensities (Nemali and van Iersel, 2004). It is not clear whether wax begonias need to be grown under shade or can be exposed to normal light inside a greenhouse during periods of high light (late spring and summer months). Wax begonias grown under a range of different DLI ( 5 to $20 \mathrm{~mol} \cdot \mathrm{m}^{-2} \cdot \mathrm{d}^{-1}$ ) for a prolonged period (4 weeks) were all found to have acceptable quality, although growth increased with an increase in DLI from 5 to $14.4 \mathrm{~mol} \cdot \mathrm{m}^{-2} \cdot \mathrm{d}^{-1}(\mathrm{Nemali}$ and van Iersel, 2004). It appears that wax begonias have the ability to acclimate and maximize carbon gain under different light intensities. However, the mechanism of this acclimation is not clear. There are few studies which quantify whole-plant acclimation responses of shade-tolerant bedding plants to different DLI. Therefore, the objective of this study was to determine the physiological responses of whole-plants of wax begonia grown under different DLI for a long duration (25 d) using photosynthesis-light response curves.

\section{Materials and Methods}

Plant material. Wax begonia 'Cocktail Vodka' seedlings were grown for a period of $25 \mathrm{~d}$ under four different DLI inside whole-plant gas exchange chambers arranged inside growth chambers (model E-15; Conviron, Winnipeg, Canada). The details of the whole-plant gas exchange system were described elsewhere (van Iersel and Bugbee, 2000). Seedlings were obtained from a commercial grower and grown in 36-cell flats $(160 \mathrm{~mL} /$ cell, Jumbo 606; TLC polyform, Plymouth, Minn.) at a spacing of 218 plants $/ \mathrm{m}^{2}$. The cell flats were filled with a soilless growing medium (Fafard 2P; Fafard Co., Anderson, S.C.) to which $\approx 1$ $\mathrm{g} /$ cell of slow-release fertilizer $(14 \mathrm{~N}-6.1 \mathrm{P}-11.6 \mathrm{~K}$; Osmocote 14-14-14; The Scotts Co., Marysville, Ohio) was added. The flats were placed in water-tight trays inside whole-plant gas exchange chambers $(0.32 \times 0.5 \times 0.6 \mathrm{~m})$. Plants were subirrigated weekly and excess water was drained from the trays after each irrigation. At the end of the 25-d growing period, plants grown at the highest DLI reached canopy closure, whereas canopy closure was not complete for plants grown at the lowest DLI.

A total of 10 gas exchange chambers and two growth chambers were used in the experiment. Out of the ten gas exchange chambers, two chambers did not contain plants and were kept outside the growth chambers. These chambers served as control chambers to detect zero drift of the differential $\mathrm{CO}_{2}$ analyzer. See Nemali and van Iersel (2004) for a more detailed description of the experimental setup, and $\mathrm{CO}_{2}$ exchange data during the 25-d growing period.

Treatments. Plants were grown under four DLI by covering individual chambers with shade cloth of varying density. The average DLI measured at the top of the canopy in different treatments was $5.3,9.5,14.4$, and $19.4 \mathrm{~mol} \cdot \mathrm{m}^{-2} \cdot \mathrm{d}^{-1}$ (corresponding to instantaneous PPF levels of $106,189,286$, and $385 \mu \mathrm{mol} \cdot \mathrm{m}^{-2 \cdot} \cdot \mathrm{s}^{-1}$ and a 14-h photoperiod, respectively). The light source was a mix of incandescent and cool-white fluorescent lamps. The PPF level was measured simultaneously in all chambers using quantum sensors (QSO; Apogee Instruments, Logan, Utah) connected to a datalogger (CR10X; Campbell Sci., Logan, Utah). The temperature inside the gas exchange chambers was maintained within $0.5^{\circ} \mathrm{C}$ of $25^{\circ} \mathrm{C}$. Aspirated type-T thermocouples were used to measure the temperature inside all gas exchange chambers. Relative humidity was measured using humidity probes (HTO-45R; Rotronic, Huntington, N.Y.).

Measurements. Twenty-five days after transplanting, 12 plants from each experimental unit were used for photosynthesis-light response curves. Before starting these measurements, plants in the different treatments were exposed to a dark period of 10 h. Subsequently, plants were exposed to increasing $P P F$ levels from 0 to $700 \mu \mathrm{mol} \cdot \mathrm{m}^{-2} \cdot \mathrm{s}^{-1}$ in approximate increments of $50 \mu \mathrm{mol} \cdot \mathrm{m}^{-2} \cdot \mathrm{s}^{-1}$. Photosynthetic photon flux was increased after the photosynthetic rate had stabilized in all treatments. On average, it took $35 \mathrm{~min}$ for the photosynthetic rate to stabilize after increasing PPF. Light-response curves of all crops were measured simultaneously.

The whole-plant gas exchange system directly measures $\mathrm{CO}_{2}$ exchange rate $\left(\mu \mathrm{mol}\right.$ of $\mathrm{CO}_{2}$ per second), i.e., dark respiration (during the dark period) and net photosynthesis $\left(\mathrm{P}_{\mathrm{n}}\right.$, during the light period) of whole plants. Gross photosynthesis was estimated by summing net photosynthesis and dark respiration rates, assuming that respiration rates in the light and dark are the same (see Amthor, 1989; van Iersel and Bugbee, 2000, for a more detailed discussion of this assumption).

Because expressing photosynthesis of whole plants per unit leaf area or on a whole-plant basis both have drawbacks (see introduction), we calculate our data both ways. Expressing the data on a whole-plant basis (or per unit ground area as we do here to keep units more easily interpretable) is a direct measure of plant growth rate in response to different $P P F$ levels, while expressing the photosynthetic rates per unit leaf area allows for the determination of acclimation responses at the leaf level. Thus, the measured CER and associated parameters were expressed per square meter ground area (hereafter, indicated by " " ") and square meter leaf area (hereafter, indicated by " " ") by dividing CER by the ground area of the gas exchange chambers $\left(0.184 \mathrm{~m}^{2}\right)$ or total leaf area of the plants, respectively.

The average $\mathrm{CO}_{2}$ concentration inside the gas exchange chambers during the light response study varied both among different DLI treatments and $P P F$ levels. The $\mathrm{CO}_{2}$ concentrations ranged from $307\left(\right.$ at $\left.\approx 700 \mu \mathrm{mol} \cdot \mathrm{m}^{-2} \cdot \mathrm{s}^{-1} P P F\right)$ to $419 \mu \mathrm{mol} \cdot \mathrm{mol}^{-1}$ (at $0 \mu \mathrm{mol} \cdot \mathrm{m}^{-2} \cdot \mathrm{s}^{-1} P P F$ ) in the highest and from 325 to 409 $\mu \mathrm{mol} \cdot \mathrm{mol}^{-1}$ in the lowest DLI treatment. These differences in $\mathrm{CO}_{2}$ concentrations may have affected the measured photosynthesis. Since $\mathrm{CO}_{2}$ concentrations were lower in the treatments with high photosynthetic rates (i.e., high DLI), these measurements would have been affected more than those with low photosynthetic rates. Therefore, differences in atmospheric $\mathrm{CO}_{2}$ concentrations may have resulted in somewhat smaller differences in CER than what would have been observed if all crops had been exposed to regular 
atmospheric $\mathrm{CO}_{2}$ concentrations $\left(\approx 380 \mu \mathrm{mol} \cdot \mathrm{mol}^{-1}\right)$.

The average air temperature was similar at all $P P F$ levels and in different DLI treatments $\left(25.3^{\circ} \mathrm{C}\right)$. The relative humidity during the 10-h dark period was higher than during the light response measurements, but was similar among the DLI treatments ( $\approx 94 \%)$. During the light response study, relative humidity ranged from $78 \%$ to $89 \%$ in the lowest and from $68 \%$ to $86 \%$ in the highest DLI treatment.

Physical growth parameters measured after the light response study included leaf area and dry weight (shoot + root dry weight) of the plants in each DLI treatment. Leaf chlorophyll concentration (of four leaves from separate plants) was assessed using a chlorophyll meter (SPAD-502; Minolta Co., Tokyo) before the light response study from each experimental unit (see Nemali and van Iersel, 2004). Total leaf area was measured using a leaf area meter (LI-3100; LI-COR, Lincoln, Nebr.)

EXPERIMENTAL DESIGN AND DATA ANALYSIS. The experimental layout was a randomized complete block with two replications. Growth chamber was the blocking factor, and each contained four gas exchange chambers exposed to different DLI levels. Each experimental unit, representing a DLI treatment, consisted of 12 plants. The photosynthesis-light response data were fitted by non-linear regression (Proc NLIN of SAS; SAS Inst., Cary, N.C.) to estimate various physiological parameters, including the dark respiration rate per square meter of leaf area and ground area

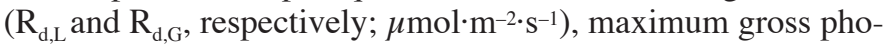
tosynthesis per square meter of leaf area and ground area $\left(\mathrm{P}_{\mathrm{g}, \max , \mathrm{L}}\right.$

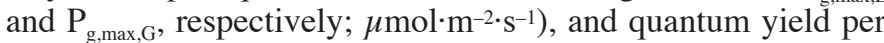
square meter leaf area and ground area $\left(\alpha_{L}\right.$ and $\alpha_{G}$, respectively; $\left.\mathrm{mol} \cdot \mathrm{mol}^{-1}\right)$. Maximum gross photosynthetic rate is the theoretical maximum photosynthetic rate of plants when $P P F$ is not limiting and estimated as the asymptote of the fitted asymptotic regression. Quantum yield is the slope of photosynthesis-light response curve at zero $P P F$ and indicates the maximum efficiency with which plants can use photons to fix $\mathrm{CO}_{2}$. The asymptotic function fitted to the CER data was:

$$
\mathrm{P}_{\mathrm{n}}=\mathrm{P}_{\mathrm{g}, \max } \times\left(1-\mathrm{e}^{-\alpha \times P P F / \mathrm{Pg}, \max }\right)-\mathrm{R}_{\mathrm{d}}
$$

where $P_{n}$ is the net photosynthetic rate per square meter leaf area $\left(P_{n, L}\right)$ or ground area $\left(P_{n, G}\right)$. Light-saturated $P_{n}\left(P_{n, \max }\right)$ can be calculated as $\mathrm{P}_{\mathrm{g}, \max }-\mathrm{R}_{\mathrm{d} \text {. }}$

The light compensation point (LCP, $\mu \mathrm{mol} \cdot \mathrm{m}^{-2} \cdot \mathrm{s}^{-1}$ ) and light saturation point (LSP, $\left.\mu \mathrm{mol} \cdot \mathrm{m}^{-2} \cdot \mathrm{S}^{-1}\right)$ were calculated by solving Eq. 1 for $\mathrm{P}_{\mathrm{g}}=\mathrm{R}_{\mathrm{d}}$ to determine LCP and $\mathrm{P}_{\mathrm{g}}=0.95 \times \mathrm{P}_{\mathrm{g}, \max }$ for LSP, respectively.

The LCP is an estimate of the $P P F$ level at which $\mathrm{P}_{\text {net }}=0$, and thus is not the $P P F$ at which there is no net $\mathrm{C}$ exchange during a 24-h period. Plants exposed to the LCP for part of a day, and in the dark for the remainder, will have a net $\mathrm{C}$ loss because of the respiration during the dark period. Here we define the net light compensation point $\left(\mathrm{LCP}_{\text {net }}\right)$ as the $P P F$ level at which there is no net $\mathrm{C}$ exchange during a $24-\mathrm{h}$ period (i.e., no net growth). The $\mathrm{LCP}_{\text {net }}$ can be estimated from the net assimilation rate (NAR, $\mu \mathrm{mol} \cdot \mathrm{m}^{-2} \cdot \mathrm{d}^{-1}$; net amount of carbon gained per square meter leaf area during a period of $24 \mathrm{~h}$ ) of plants.

The NAR at each $P P F$ level was estimated as:

$\mathrm{NAR}=\left(\mathrm{P}_{\mathrm{n}, \mathrm{L}} \times \mathrm{t}_{\text {light }}\right)-\left(\mathrm{R}_{\mathrm{d}, \mathrm{L}} \times \mathrm{t}_{\text {dark }}\right)$

where $t_{\text {light }}$ and $t_{\text {dark }}$ are the duration of the light (50400 s) and dark periods (36000 s) periods, respectively. A nonlinear regression was fitted to describe the relationship between NAR and PPF:

$\mathrm{NAR}=\mathrm{NAR}_{\text {min }}+\left(\mathrm{NAR}_{\max }-\mathrm{NAR}_{\min }\right) \times\left(1-\mathrm{e}^{-\mathrm{b} \times P P F}\right)$ where $\mathrm{NAR}_{\text {min }}=\mathrm{NAR}$ when $P P F=0$ (i.e., $\mathrm{R}_{\mathrm{d}, \mathrm{L}}$ during a 24-h period) and $\mathrm{NAR}_{\max }=$ theoretical maximum NAR (asymptote).
The $\mathrm{LCP}_{\text {net }}$ was determined as the $P P F$ level at which $\mathrm{NAR}=0$ $\mu \mathrm{mol} \cdot \mathrm{m}^{-2} \cdot \mathrm{d}^{-1}$.

Net and gross light-use efficiency (LUE ${ }_{\text {net }}$ and LUE gross $_{\text {, mols }}$ of $\mathrm{CO}_{2}$ fixed per mol of incident $P P F$ ) of plants was estimated from $\mathrm{P}_{\mathrm{n}}$ and $\mathrm{P}_{\mathrm{g}}$, respectively:

$\mathrm{LUE}=\mathrm{P}_{\mathrm{n}}$ or $\mathrm{P}_{\mathrm{g}} / P P F$

At a $P P F$ of $0 \mu \mathrm{mol} \cdot \mathrm{m}^{-2} \cdot \mathrm{s}^{-1}$, LUE cannot be estimated from Eq. 4. However, $\alpha$ is an estimate of the maximum $\mathrm{LUE}_{\text {gross }}$, which occurs at extremely low $P P F$ and therefore was used as the estimated $\mathrm{LUE}_{\text {gross }}$ at $0 \mu \mathrm{mol} \cdot \mathrm{m}^{-2} \cdot \mathrm{s}^{-1} P P F$. LUE was determined both on a ground and leaf area basis.

The effects of the DLI during the growing period on the estimated photosynthetic parameters were analyzed by testing for significant linear and quadratic trends with respect to DLI $(P<$ $0.05)$. Other correlations were tested with multiple regression (e.g., dependence of LCP on $\mathrm{R}_{\mathrm{d}}$ and $\alpha$ ).

\section{Results and Discussion}

Plant Size AND Chlorophyll CONCENTRation. Physical growth measurements indicated that total dry weight and leaf area of plants increased with increasing DLI (Table 1). Leaf chlorophyll concentration decreased with increasing DLI during growth (Table 1 ), but this decrease was small (up to 6.3\%). Increased levels of chlorophyll per chloroplast, chlorophyll per unit dry weight (Lambers et al., 1998), and increased chlorophyll $b / a$ ratio (Adams and Demmig-Adams, 1992; Close et al., 2001; Lambers et al., 1998) have been reported as associated with shading. An increase in leaf chlorophyll concentration enables shade-grown plants to more efficiently capture light and thus maximize photosynthesis under low DLI conditions. Earlier results (Nemali and van Iersel, 2004) indicated that leaf area ratio (total leaf area/total dry weight) and shoot/root ratio (shoot dry weight/root dry weight) of these plants were not affected by DLI treatments.

Photosynthesis AND Respiration. There was a close relationship between $\mathrm{P}_{\mathrm{n}}$ (both per square meter leaf area and square meterground area) of wax begonia and $P P F$ in all DLI treatments (Fig. 1, $0.97<R^{2}<0.99$ ). Net photosynthesis of plants in all DLI treatments increased rapidly as $P P F$ was increased from 0 to 200 $\mu \mathrm{mol} \cdot \mathrm{m}^{-2} \cdot \mathrm{s}^{-1}$, and $\mathrm{P}_{\mathrm{n}}$ became light-saturated at $\approx 530 \mu \mathrm{mol} \cdot \mathrm{m}^{-2 \cdot} \cdot \mathrm{s}^{-1}$ (Fig. 1, Tables 1 and 2). On a ground area basis, DLI effects on $\mathrm{P}_{\mathrm{n}}$ were evident at $P P F$ levels above $50 \mu \mathrm{mol} \cdot \mathrm{m}^{-2} \cdot \mathrm{s}^{-1}$ and consistently grew larger with increasing $P P F$ (Fig. 1A). Above a $P P F$ of 50 $\mu \mathrm{mol} \cdot \mathrm{m}^{-2} \cdot \mathrm{s}^{-1}, \mathrm{P}_{\mathrm{n}, \mathrm{G}}$ was consistently higher for plants grown at the highest DLI than for those grown at low DLI. However, $\mathrm{P}_{\mathrm{n}, \mathrm{G}}$ of plants in the two highest DLI treatments $\left(14.4\right.$ and $\left.19.4 \mathrm{~mol} \cdot \mathrm{m}^{-2} \cdot \mathrm{d}^{-1}\right)$ was similar at all $P P F$ levels. On a leaf area basis, the effect of

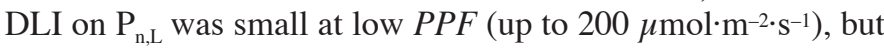
increased at higher PPF levels (Fig. 1B). Above a PPF of 200 $\mu \mathrm{mol} \cdot \mathrm{m}^{-2} \cdot \mathrm{s}^{-1}$, plants grown at the highest DLI $\left(19.4 \mathrm{~mol} \cdot \mathrm{m}^{-2} \cdot \mathrm{d}^{-1}\right)$ consistently had a higher $\mathrm{P}_{n, \mathrm{~L}}$ than those grown at other DLI treatments. The $P_{n, L}$ of plants grown at a DLI of $9.5 \mathrm{~mol} \cdot \mathrm{m}^{-2} \cdot \mathrm{d}^{-1}$ was lower than the plants grown under the lowest DLI treatment (5.3 $\left.\mathrm{mol} \cdot \mathrm{m}^{-2} \cdot \mathrm{d}^{-1}\right)$ throughout the experiment (Fig. 1B). This may be due to the larger leaf area and increased intra-canopy shading at a DLI of $9.5 \mathrm{~mol} \cdot \mathrm{m}^{-2} \cdot \mathrm{d}^{-1}$, as compared to $5.3 \mathrm{~mol} \cdot \mathrm{m}^{-2} \cdot \mathrm{d}^{-1}$.

Dark respiration rates of plants (both per $\mathrm{m}^{2}$ ground area and square meter leaf area) increased with increasing DLI (Fig. 1 , Tables 1 and 2$)$. Specific respiration rate $\left(\mathrm{R}_{\mathrm{spec}}, \mu \mathrm{mol} \cdot \mathrm{g}^{-1} \cdot \mathrm{s}^{-1}\right.$; estimated as $\mathrm{R}_{\mathrm{d}}$ /total dry weight) increased with increasing DLI $\left(\mathrm{R}_{\text {spec }}=0.0086+0.00043 \times \mathrm{DLI}, r^{2}=0.73\right)$. Decreased wholeplant respiration with decreasing DLI also has been reported for 
Table 1. Effect of daily light integral (DLI) during growth on photosynthesis-light response parameters of groups of 12 wax begonias. Estimated values (per square meter ground area) are quantum yield $\left(\alpha_{\mathrm{G}}\right)$, maximum gross photosynthesis $\left(\mathrm{P}_{\mathrm{g}, \mathrm{max}, \mathrm{G}}\right)$, dark respiration rate $\left(\mathrm{R}_{\mathrm{d}, \mathrm{G}}\right)$, maximum net photosynthesis $\left(\mathrm{P}_{\text {nmax,G }}\right)$, light compensation point $\left(\mathrm{LCP}_{\mathrm{G}}\right)$, light saturation point $\left(\mathrm{LSP}_{\mathrm{G}}\right)$, total dry weight (TDW), leaf chlorophyll concentration (chl, from Nemali and van Iersel, 2004), and total leaf area (LA). Intercept and slope of the regression $(y=a+b \times D L I)$ are shown when the slope was statistically significant; otherwise, the intercept indicates the mean value.

\begin{tabular}{|c|c|c|c|c|c|c|c|c|c|}
\hline $\begin{array}{l}\text { DLI } \\
\left(\mathrm{mol} \cdot \mathrm{m}^{-2} \cdot \mathrm{d}^{-1}\right)\end{array}$ & $\begin{array}{c}\alpha_{\mathrm{G}} \\
\left(\mathrm{mol} \cdot \mathrm{mol}^{-1}\right)\end{array}$ & $\begin{array}{c}\mathrm{P}_{\mathrm{g}, \mathrm{max}, \mathrm{G}} \\
\left(\mu \mathrm{mol} \cdot \mathrm{m}^{-2} \cdot \mathrm{s}^{-1}\right)\end{array}$ & $\begin{array}{c}\mathrm{R}_{\mathrm{d}, \mathrm{G}} \\
\left(\mu \mathrm{mol} \cdot \mathrm{m}^{-2} \cdot \mathrm{s}^{-1}\right)\end{array}$ & $\begin{array}{c}\mathrm{P}_{\mathrm{n}, \mathrm{max}, \mathrm{G}} \\
\left(\mu \mathrm{mol} \cdot \mathrm{m}^{-2} \cdot \mathrm{s}^{-1}\right)\end{array}$ & $\begin{array}{c}\mathrm{LCP}_{\mathrm{G}} \\
\left(\mu \mathrm{mol} \cdot \mathrm{m}^{-2} \cdot \mathrm{s}^{-1}\right)\end{array}$ & $\begin{array}{c}\mathrm{LSP}_{\mathrm{G}} \\
\left(\mu \mathrm{mol} \cdot \mathrm{m}^{-2} \cdot \mathrm{s}^{-1}\right)\end{array}$ & $\begin{array}{l}\text { TDW } \\
(\mathrm{g})\end{array}$ & $\begin{array}{c}\text { chl } \\
\text { (spad units) }\end{array}$ & $\begin{array}{l}\text { LA } \\
\left(\mathrm{m}^{2}\right)\end{array}$ \\
\hline 5.3 & 0.037 & 5.83 & 0.60 & 5.23 & 17.66 & 476 & 9.84 & 30.3 & 0.29 \\
\hline 9.5 & 0.041 & 7.47 & 0.77 & 6.70 & 20.12 & 556 & 12.52 & 29.3 & 0.38 \\
\hline 14.4 & 0.057 & 10.63 & 1.45 & 9.18 & 27.28 & 560 & 16.79 & 29.2 & 0.47 \\
\hline 19.4 & 0.069 & 10.92 & 1.57 & 9.41 & 25.90 & 522 & 16.82 & 28.4 & 0.48 \\
\hline & \multicolumn{9}{|c|}{ Regression } \\
\hline$r^{2}$ & 0.70 & 0.79 & 0.81 & 0.77 & 0.63 & NS & 0.84 & 0.71 & 0.80 \\
\hline Intercept & 0.024 & 3.77 & $0.18^{\mathrm{Ns}}$ & 3.10 & 13.91 & 528 & 7.40 & 30.7 & 0.23 \\
\hline Slope & 0.0021 & 0.42 & 0.076 & 0.29 & 0.75 & --- & 0.55 & -0.11 & 0.015 \\
\hline
\end{tabular}

NsNonsignificant at $P=0.05$.
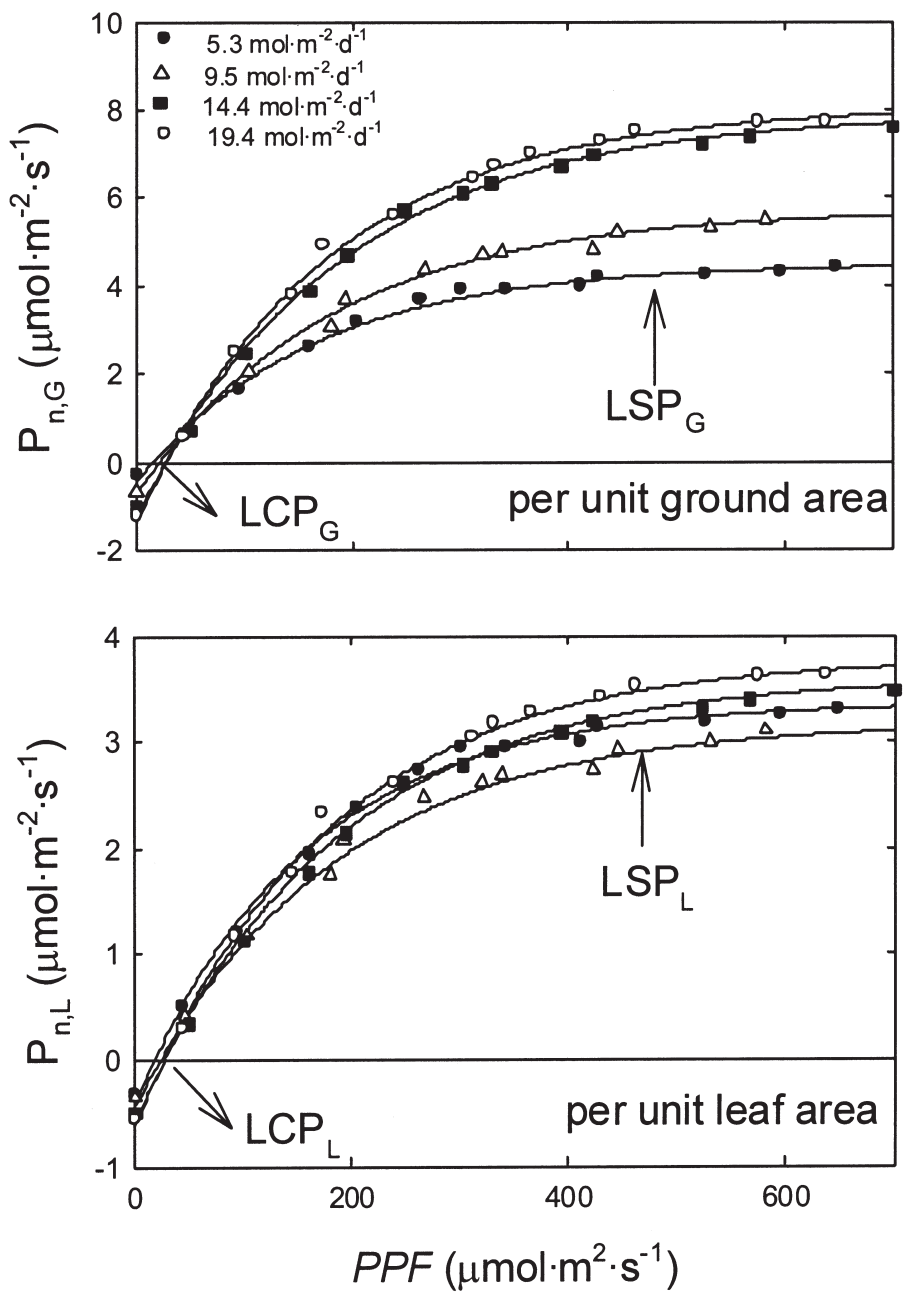

Fig. 1. Response of net photosynthesis per square meter ground area $\left(\mathrm{P}_{\mathrm{n}, \mathrm{G}}\right)$ and per square meter leaf area $\left(\mathrm{P}_{\mathrm{n}, \mathrm{L}}\right)$ to photosynthetic photon flux $(P P F)$ in wax begonia. Before determining the $P P F$ responses, plants were grown under four different daily light integrals (DLI) for a period of $25 \mathrm{~d}$. Symbols indicate DLI of $5.3(\bullet), 9.5(\Delta), 14.4(\square)$, and $19.4(O) \mathrm{mol} \cdot \mathrm{m}^{-2} \cdot \mathrm{d}^{-1}$. See Tables 1 and 2 for regression parameters $\left(0.97<R^{2}<0.99\right)$. Data represent the mean of two replications. zantedeschia (Zantedeschia Spreng.; Funnell et al., 2002) and stokes aster [Stokesia laevis (Hill) E. Greene; Callan and Kennedy, 1995]. A decrease in $R_{\text {spec }}$ will increase net carbon gain under low DLI conditions and can be considered an acclimation response to low DLI (Reich et al., 2003).

QUANTUM YIELD. As quantum yield was estimated as mols of $\mathrm{CO}_{2}$ fixed per unit incident light, and not per unit absorbed light, the fraction of incident $P P F$ intercepted by the plants affected quantum yield of plants. Thus, $\alpha_{\mathrm{G}}$ increased with increasing DLI, at least partly due to larger leaf area and thereby, more light interception by plants with increasing DLI. The estimated values of $\alpha_{\mathrm{G}}$ ranged from 0.037 to $0.069 \mathrm{~mol} \cdot \mathrm{mol}^{-1}$ (Fig. 1A, Table 1$)$. There were no differences in $\alpha_{L}$ among DLI treatments and $\alpha_{L}$ averaged 0.023 mol. mol-1 $^{-1}$ (Fig. 1B, Table 2). Our finding that $\alpha_{L}$, the maximum photosynthetic efficiency per unit leaf area, was not affected by DLI during growth supports previous findings (Close et al., 2001; Luo et al., 2000; Thornley, 1998). However, using whole-plant measurements, Funnel et al (2002) found that $\alpha_{L}$ of zantedeschia was higher for plants grown at low $\left(348 \mu \mathrm{mol} \cdot \mathrm{m}^{-2} \cdot \mathrm{s}^{-1}\right)$ than for those grown at high $\left(694 \mu \mathrm{mol} \cdot \mathrm{m}^{-2} \cdot \mathrm{s}^{-1}\right) P P F$.

Other estimates of $\alpha$ from whole-plant CER measurements have yielded similar results to ours. Giaglaras et al. (1995) reported the measured $\alpha_{\mathrm{G}}$ of begonia (Begonia $\times$ heimalis Fotsch.) as 0.066 mol·mol-1. Miller et al. (2001) reported $\alpha_{\mathrm{L}}$ of two cultivars of angelonia (Angelonia angustifolia Beneth) as 0.026 and 0.038 $\mathrm{mol} \cdot \mathrm{mol}^{-1}$, while alstroemeria 'Jacqueline' (Alstroemeria L.) was reported to have an $\alpha_{\mathrm{L}}$ of $0.019 \mathrm{~mol} \cdot \mathrm{mol}^{-1}$ (Leonardos et al., 1994). Funnell et al. (2002) reported that $\alpha_{L}$ of zantedeschia ranged from 0.016 to $0.029 \mathrm{~mol} \cdot \mathrm{mol}^{-1}$. However, comparisons of $\alpha$ estimates from different studies are difficult, because the plants likely absorbed different fractions of the incident light.

Light COMPENSATION POINT. There was an increase in the $\mathrm{LCP}_{\mathrm{G}}$, but no significant change in the $\mathrm{LCP}_{\mathrm{L}}$ with increasing DLI. The $\mathrm{LCP}_{\mathrm{G}}$ ranged from 18 to $27 \mu \mathrm{mol} \cdot \mathrm{m}^{-2} \cdot \mathrm{s}^{-1}$ (Table 1 ), while $\mathrm{LCP}_{\mathrm{L}}$ averaged $23.2 \mu \mathrm{mol} \cdot \mathrm{m}^{-2} \cdot \mathrm{s}^{-1}$. Since $\mathrm{R}_{\mathrm{d}}$ generally is higher with increasing DLI, plants grown at a high DLI need to photosynthesize more to offset respiration and will often have a higher LCP than those grown under low DLI. For example, the LCP of whole-plants of stokes aster grown at PPF levels of 120 , 320 , and $1010 \mu \mathrm{mol} \cdot \mathrm{m}^{-2} \cdot \mathrm{s}^{-1}$ was 25,55 , and $185 \mu \mathrm{mol} \cdot \mathrm{m}^{-2} \cdot \mathrm{s}^{-1}$, respectively (Callan and Kennedy, 1995). However, Norcini et al. (1991) reported that the LCP of eastern redbud (Cercis canadensis L.) was not affected by preconditioning plants to either sun or shade. 
Table 2. Effect of daily light integral (DLI) during growth on photosynthesis-light response parameters of groups of 12 wax begonias. Estimated values (per $\mathrm{m}^{2}$ leaf area) are quantum yield $\left(\alpha_{\mathrm{L}}\right)$, maximum gross photosynthesis $\left(\mathrm{P}_{\mathrm{g}, \max , \mathrm{L}}\right)$, dark respiration rate $\left(\mathrm{R}_{\mathrm{d}, \mathrm{L}}\right)$, light compensation point $\left(\mathrm{LCP}_{\mathrm{L}}\right)$, net light compensation point $\left(\mathrm{LCP}_{\text {net }}\right)$, and light saturation point $\left(\operatorname{LSP}_{\mathrm{L}}\right)$. Intercept and slope of the regression $(y=a+b \times D L I)$ are shown when the slope was statistically significant; otherwise, the intercept indicates the mean value.

\begin{tabular}{lcccccc}
\hline $\begin{array}{l}\text { DLI } \\
\left(\mathrm{mol} \cdot \mathrm{m}^{-2} \cdot \mathrm{d}^{-1}\right)\end{array}$ & $\begin{array}{c}\alpha_{\mathrm{L}} \\
\left(\mathrm{mol} \cdot \mathrm{mol}^{-1}\right)\end{array}$ & $\begin{array}{c}\mathrm{P}_{\mathrm{g}, \max , \mathrm{L}} \\
\left(\mu \mathrm{mol} \cdot \mathrm{m}^{-2} \cdot \mathrm{s}^{-1}\right)\end{array}$ & $\begin{array}{c}\mathrm{R}_{\mathrm{d}, \mathrm{L}} \\
\left(\mu \mathrm{mol} \cdot \mathrm{m}^{-2} \cdot \mathrm{s}^{-1}\right)\end{array}$ & $\begin{array}{c}\mathrm{LCP}_{\mathrm{L}} \\
\left(\mu \mathrm{mol} \cdot \mathrm{m}^{-2} \cdot \mathrm{s}^{-1}\right)\end{array}$ & $\begin{array}{c}\mathrm{LCP}_{\text {net }} \\
\left(\mu \mathrm{mol} \cdot \mathrm{m}^{-2} \cdot \mathrm{s}^{-1}\right)\end{array}$ & $\begin{array}{c}\mathrm{LSP}_{\mathrm{L}} \\
\left(\mu \mathrm{mol}^{-} \cdot \mathrm{m}^{-2} \cdot \mathrm{s}^{-1}\right)\end{array}$ \\
\hline 5.3 & 0.024 & 3.76 & 0.39 & 17.7 & 29.3 & 477 \\
9.5 & 0.020 & 3.61 & 0.43 & 20.1 & 34.9 & 556 \\
14.4 & 0.022 & 4.17 & 0.57 & 29.1 & 46.7 & 596 \\
19.4 & 0.023 & 4.39 & 0.61 & 25.9 & 45.1 & 522 \\
& & & & & \\
$r^{2}$ & $\mathrm{NS}$ & 0.76 & 0.72 & Regression & 0.70 & $\mathrm{NS}$ \\
Intercept & 0.023 & 3.37 & 0.26 & 23.2 & 22.7 & 538 \\
Slope & -- & 0.05 & 0.0183 & -- & 1.37 & -- \\
\hline
\end{tabular}

NsNonsignificant at $P=0.05$.

The light compensation point of wax begonia was lower than that of angelonia ( 67 to $86 \mu \mathrm{mol} \cdot \mathrm{m}^{-2} \cdot \mathrm{s}^{-1}$; Miller et al., 2001), and close to that of Rosa hybrida L. 'Sonia' $\left(29 \mu \mathrm{mol} \cdot \mathrm{m}^{-2} \cdot \mathrm{s}^{-1}\right.$, Baille et al., 1996) and Alstroemaria 'Jacqueline' (21 $\mu \mathrm{mol} \cdot \mathrm{m}^{-2} \cdot \mathrm{s}^{-1}$; Leonardos et al., 1994), all estimated from whole-plant measurements. The light compensation point could be accurately described with a regression equation including both $\mathrm{R}_{\mathrm{d}}$ and $\alpha\left(\mathrm{LCP}_{\mathrm{G}}\right.$ $=23.5+24.3 \times \mathrm{R}_{\mathrm{d}, \mathrm{G}}-550 \times \alpha_{\mathrm{G}}, R^{2}=0.99$ and $\mathrm{LCP}_{\mathrm{L}}=$ $\left.19.2+48.9 \times \mathrm{R}_{\mathrm{d}, \mathrm{L}}-862 \times \alpha_{\mathrm{L}} ; R^{2}=0.98\right)$. This indicates that LCP increased with increasing $\mathrm{R}_{\mathrm{d}}$ and decreased with increasing $\alpha$.

LIGHT SATURATION POINT. Net photosynthesis of wax begonias reached light-saturation at $\approx 530 \mu \mathrm{mol} \cdot \mathrm{m}^{-2} \cdot \mathrm{s}^{-1}$ (Fig. 1, Tables 1 and 2). Usually, photosynthesis of plants grown at a high DLI saturate at a higher $P P F$ than those grown at a low DLI, mainly due to higher amounts of Rubisco (Callan and Kennedy, 1995; Funnell et al., 2002). However, the LSP of soybean (Glycine max L.) grown at either high $\left(1000-1500 \mu \mathrm{mol} \cdot \mathrm{m}^{-2} \cdot \mathrm{s}^{-1}\right)$ or low (250-500 $\left.\mu \mathrm{mol} \cdot \mathrm{m}^{-2} \cdot \mathrm{s}^{-1}\right) P P F$ did not differ significantly (Seemann, 1989). Canopies reach light-saturation at a higher $P P F$ than individual leaves. This is due to intracanopy shading resulting in low $P P F$ incident on the bottom leaves; therefore, the leaves at the bottom part of the canopy rarely reach light-saturation. For example, leaf net photosynthesis of alstroemaria 'Jacqueline' reached light saturation at $\approx 600 \mu \mathrm{mol} \cdot \mathrm{m}^{-2} \cdot \mathrm{s}^{-1}$, whereas that of whole plants reached light saturation above $1200 \mu \mathrm{mol} \cdot \mathrm{m}^{-2} \cdot \mathrm{s}^{-1}$ (Leonardos et al., 1994). The $P P F$ at which wax begonia plants became lightsaturated $\left(530 \mu \mathrm{mol} \cdot \mathrm{m}^{-2} \cdot \mathrm{s}^{-1}\right)$ was only $\approx 26 \%$ of maximum sun light $\left(\approx 2000 \mu \mathrm{mol} \cdot \mathrm{m}^{-2} \cdot \mathrm{s}^{-1}\right)$. This low LSPlimits the photosynthetic capacity of wax begonias as these plants are not able to utilize high $P P F$ levels.

Maximum GRoss Photosynthesis. Both $\mathrm{P}_{\mathrm{g}, \max , \mathrm{G}}$ and $\mathrm{P}_{\mathrm{g}, \max , \mathrm{L}}$ of wax begonia increased with increasing DLI (Fig. 1, Tables 1 and 2). The values of $P_{g, \text { max,G }}$ for plants under different DLI treatments ranged from 5.83 to $10.92 \mu \mathrm{mol} \cdot \mathrm{m}^{-2} \cdot \mathrm{s}^{-1}$ (Table 1 ), and $\mathrm{P}_{\mathrm{g}, \max , \mathrm{L}}$ ranged from 3.61 to $4.39 \mu \mathrm{mol} \cdot \mathrm{m}^{-2} \cdot \mathrm{s}^{-1}$ (Table 2). This indicates that under light-saturated conditions, canopies grown under high DLI were able to photosynthesize more than those grown under low DLI, both on a ground area and leaf area basis. Apparently, wax begonia has the ability the increase its $\mathrm{P}_{\mathrm{g}, \max }$ in response to increasing DLI. This could be due to a higher Rubisco content in plants grown under high DLI, as its concentration is

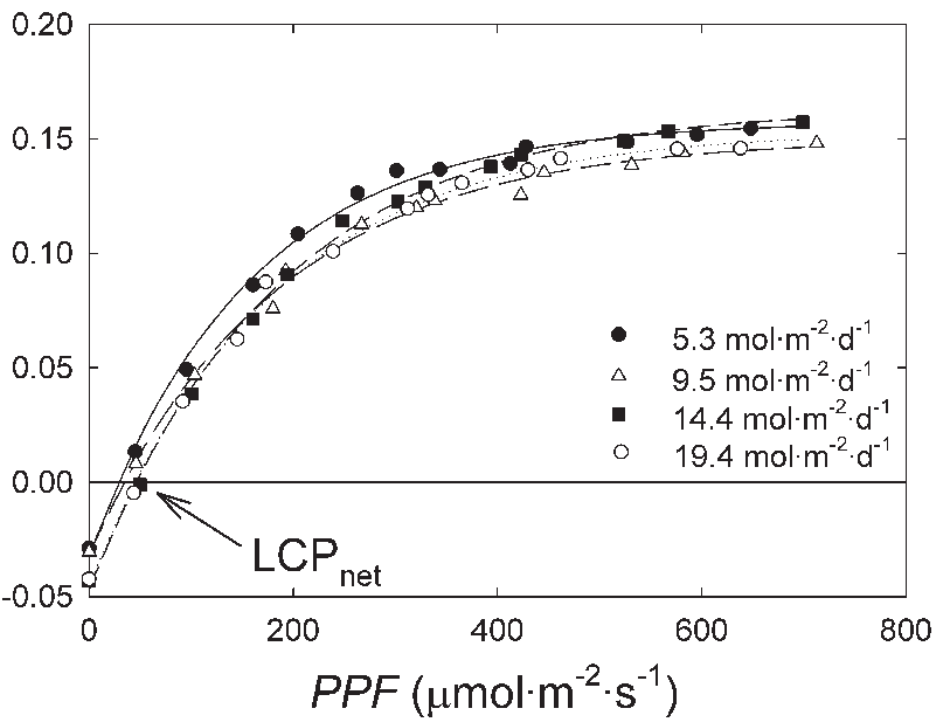
begonia plants grown at daily light integrals (DLI) of $5.3(\bullet), 9.5(\Delta), 14.4(\square)$, and 19.4 (O) $\mathrm{mol} \cdot \mathrm{m}^{-2} \cdot \mathrm{d}^{-1}$. The net light compensation point $\left(\mathrm{LCP}_{\text {net }}\right)$ represents the PPF at which here is zero net carbon uptake. An asymptotic equation (Eq. 3) was fitted to describe the lationship $\left(0.97<R^{2}<0.99\right)$. Data represent the mean of two replications.

the single factor most commonly limiting photosynthesis at high PPF (von Caemmerer and Farquhar, 1981). Other studies have indeed reported increased amounts of Rubisco in plants grown at a high DLI (Parry et al., 2003; Rosati et al., 1999; Warren and Adams, 2001).

Our study also indicated that wax begonias have a low $\mathrm{P}_{\mathrm{g}, \max }$ compared to other crop species. Other reported values of $\mathrm{P}_{\mathrm{g}, \max , \mathrm{L}}$ for whole-plants are $10.5 \mu \mathrm{mol} \cdot \mathrm{m}^{-2} \cdot \mathrm{s}^{-1}$ for alstroemeria (Leonardos et al.,1994), $13.5 \mu \mathrm{mol} \cdot \mathrm{m}^{-2} \cdot \mathrm{s}^{-1}$ for rose (Baille et al., 1996), and 6 to $10 \mu \mathrm{mol} \cdot \mathrm{m}^{-2 \cdot} \mathrm{s}^{-1}$ for zantedeschia (Funnell et al., 2002). The lower $\mathrm{P}_{\mathrm{g}, \max , \mathrm{L}}$ of wax begonias as compared to other species could be due to their low LSP and their inability to use high $P P F$ levels efficiently. There was a strong correlation between $\mathrm{P}_{\mathrm{g}, \max , \mathrm{G}}$ and $\mathrm{R}_{\mathrm{d}, \mathrm{G}}\left(\mathrm{P}_{\mathrm{g}, \max },{ }_{\mathrm{G}}=2.85+5.432 \times \mathrm{R}_{\mathrm{d}, \mathrm{G}} ; r^{2}=0.96\right)$, while $\mathrm{P}_{\mathrm{g}, \max , \mathrm{L}}$ depended on both $\mathrm{R}_{\mathrm{d}, \mathrm{L}}$ and $\alpha_{\mathrm{L}}\left(\mathrm{P}_{\mathrm{g}, \max , \mathrm{L}}=1.8+2.64 \times \mathrm{R}_{\mathrm{d}, \mathrm{L}}+39.3 \times\right.$ $\left.\alpha_{\mathrm{L}}, R^{2}=0.85\right)$. Thus, $\mathrm{P}_{\mathrm{g} \text { max } \mathrm{L}}$ of wax begonia increased with both increasing $R_{\mathrm{d}, \mathrm{L}}$ and $\alpha_{\mathrm{L}}$.

NET ASSIMILATION RATE. The NAR of plants increased asymptotically with increasing $P P F\left(R^{2}=0.98 ;\right.$ Fig. 2$)$. The estimated 


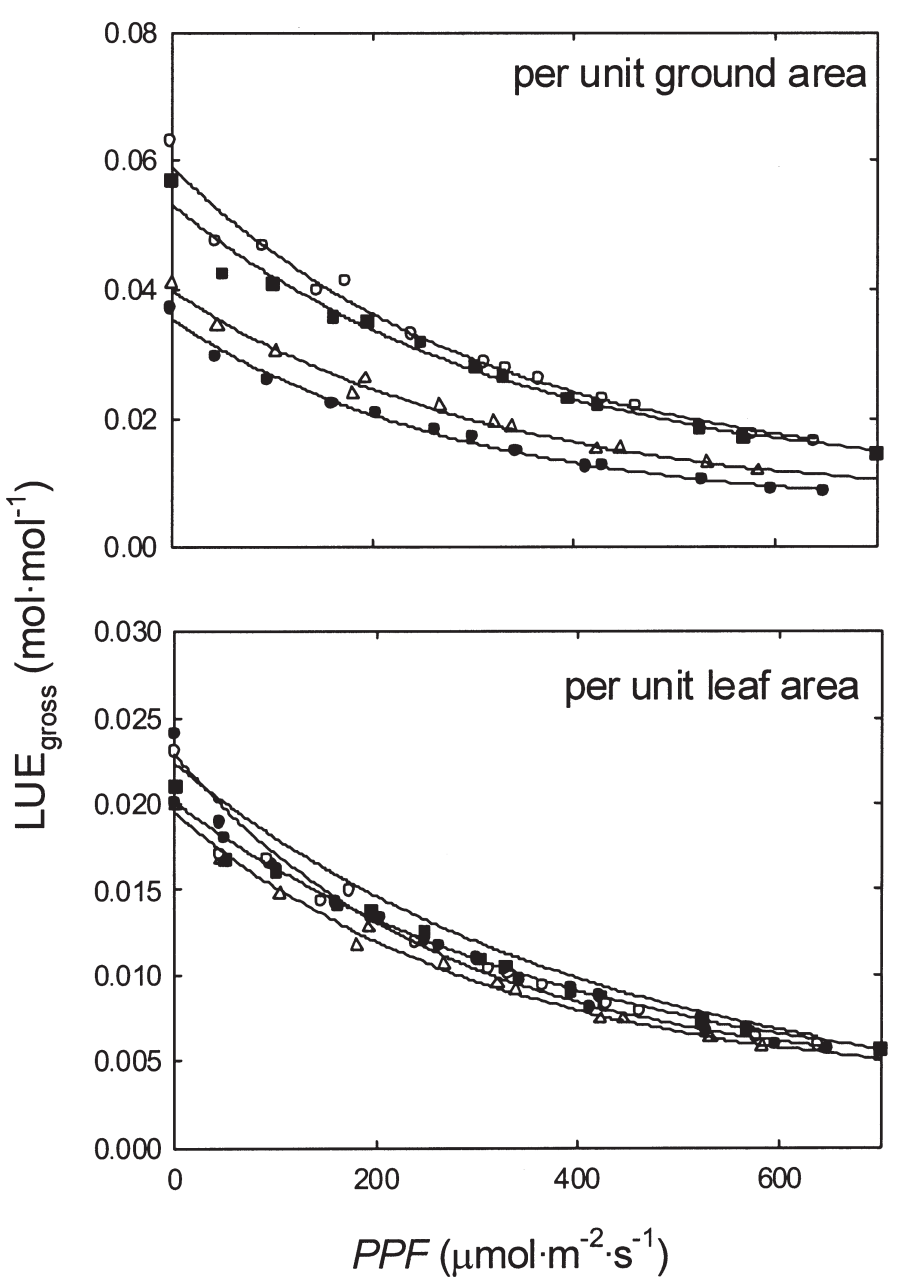

Fig. 3. Effect of photosynthetic photon flux ( $P P F)$ on gross light-use efficiency $\left(\mathrm{LUE}_{\text {oross }}\right)$ of wax begonia plants, calculated from gross photosynthesis per $\mathrm{m}^{2}$ ground area and per square meter leaf area. Data points represent the average of two replications. Symbols indicate DLI of $5.3(\bullet), 9.5(\Delta), 14.4(\square)$, and 19.4 (O) $\mathrm{mol} \cdot \mathrm{m}^{-2 \cdot} \mathrm{d}^{-1}$. A nonlinear regression, $\mathrm{LUE}_{\text {gross }}=\mathrm{a}+\mathrm{b} \times\left(\mathrm{e}^{-\mathrm{c} \times P P F}\right)$, was fitted to the data $\left(0.97<R^{2}<0.99\right)$. Regression coefficients $(\mathrm{a}, \mathrm{b}$, and $\mathrm{c})$ at each DLI are indicated in parentheses. Per square meter ground area: $5.3(0.0061,0.0294$, $0.00355), 9.5(0.0069,0.0331,0.00316), 14.4(0.0094,0.0439,0.00296), 19.4$ $(0.0104,0.0487,0.00319) \mathrm{mol} \cdot \mathrm{m}^{-2} \cdot \mathrm{d}^{-1}$ and per unit leaf area: $5.3(0.0040,0.0188$, 0.00365), 9.5 (0.0033, 0.0162, 0.00313), 14.4 (0.0026, 0.0175, 0.00247), 19.4 $(0.0019,0.0204,0.00238) \mathrm{mol} \cdot \mathrm{m}^{-2} \cdot \mathrm{d}^{-1}$, respectively.

$\mathrm{NAR}_{\max }$ was not significantly different among DLI treatments and averaged $0.15 \mathrm{~mol} \cdot \mathrm{m}^{-2} \cdot \mathrm{d}^{-1}$. Regression analysis indicated that $\mathrm{LCP}_{\text {net }}\left(\mathrm{NAR}=0 \mathrm{~mol} \cdot \mathrm{m}^{-2} \cdot \mathrm{d}^{-1}\right)$ increased with increasing DLI (Table 2) and ranged from 29 to $47 \mu \mathrm{mol} \cdot \mathrm{m}^{-2} \cdot \mathrm{s}^{-1}$. This indicates that to offset respiration during a 24-h period, plants grown at high DLI need to be exposed to higher $P P F$ than those grown at low DLI, even though there were no differences in $\mathrm{LCP}_{\mathrm{L}}$.

LighT-USE EFFICIENCY. The ratio of gross photosynthesis to $P P F\left(\mathrm{LUE}_{\text {gross }}\right)$, indicates the efficiency with which plants use the incident $P P F$ to fix $\mathrm{C}$ (i.e., it does not account for dark respiration). Gross LUE decreased with increasing $P P F$ (Fig. 3). When expressed on a ground area basis, $\mathrm{LUE}_{\mathrm{gross}}$ increased with increasing DLI, independent of PPF level (Fig. 3A). This was likely caused by increased light interception by plants grown under high DLI since differences in $\mathrm{LUE}_{\text {gross }, \mathrm{L}}$ among DLI treatments were small (Fig. 3B).

Net LUE $\left(\mathrm{P}_{\mathrm{n}} / P P F\right)$ accounts for the effect of $\mathrm{R}_{\mathrm{d}}$ and is a better indicator than $\mathrm{LUE}_{\text {gross }}$ for how efficiently plants use light

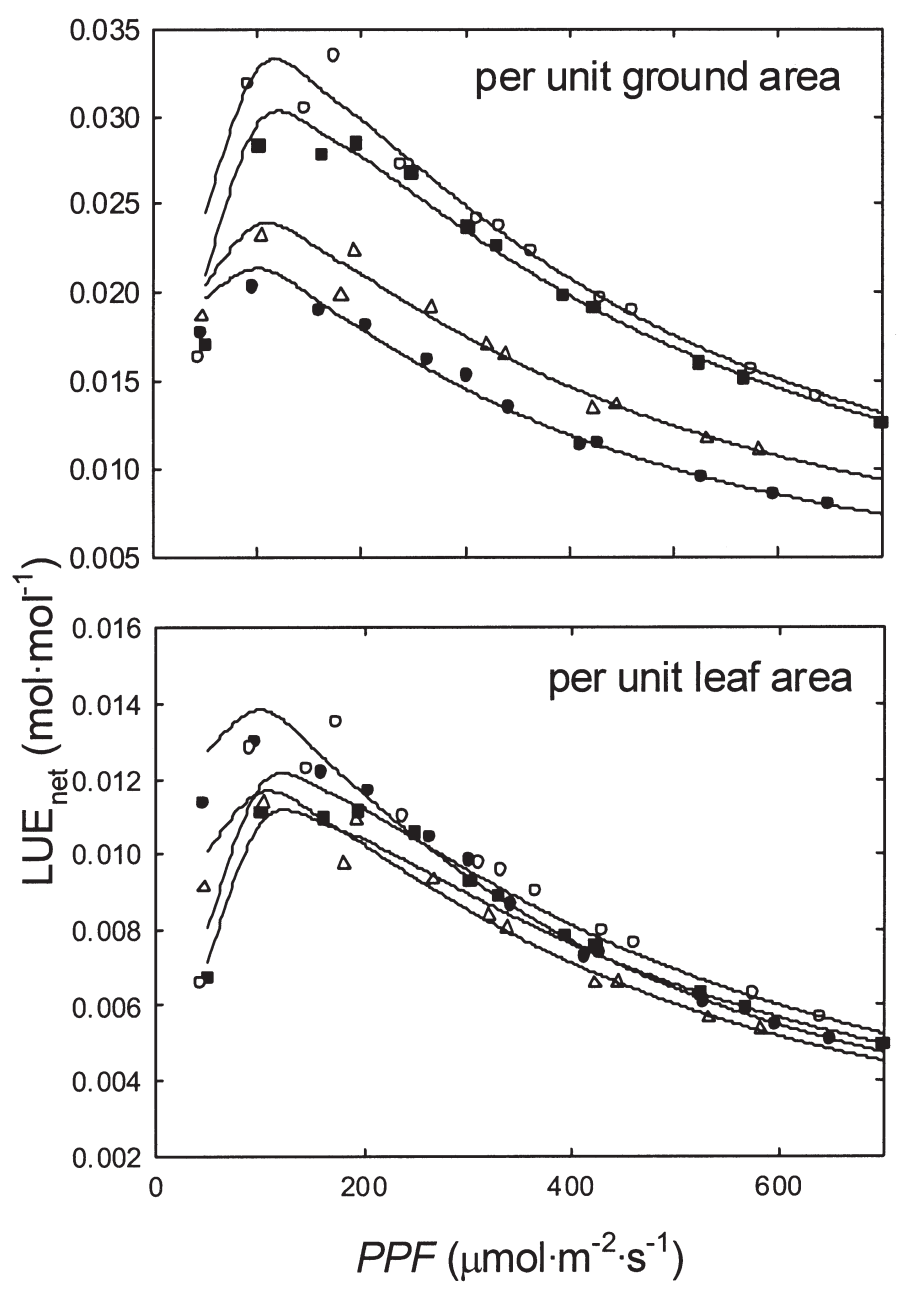

Fig. 4. Effect of increasing photosynthetic photon flux $(P P F)$ on net light-use efficiency ( $\mathrm{LUE}_{\text {gross }}$ ) of wax begonia plants calculated from net photosynthesis per square meter ground area and per square meter leaf area. Data represent the average of two replications. Symbols indicate a growth period DLI of 5.3 $(\bullet), 9.5(\Delta), 14.4(\square)$, and $19.4(\bigcirc) \mathrm{mol} \cdot \mathrm{m}^{-2} \cdot \mathrm{d}^{-1}$. Regression lines were drawn according to $\mathrm{P}_{\mathrm{n}} / P P F=\left(\mathrm{P}_{\mathrm{g}, \max } \times\left(1-\mathrm{e}^{-\alpha \times P P F / \mathrm{Pg}, \max }\right)-\mathrm{R}_{\mathrm{d}}\right) / P P F$, using the regression coefficients from Tables 1 and 2 .

for growth. Maximum $L_{U E}$ net occurred at a $P P F$ of 100 to 150 $\mu \mathrm{mol} \cdot \mathrm{m}^{-2 \cdot} \mathrm{s}^{-1}$, irrespective of DLI (Fig. 4). At low $P P F, \mathrm{R}_{\mathrm{d}}$ causes a relatively large reduction in $P_{n}$, which in turn results in a low net LUE. This effect is greater for plants grown at high DLI, because their $R_{d}$ is higher (Table 1). This explains the decrease in $L_{\text {net }}$ per unit leaf area with increasing DLI at a $P P F$ of 50 $\mu \mathrm{mol} \cdot \mathrm{m}^{-2} \cdot \mathrm{s}^{-1}$. At high $P P F$, photosynthesis is approaching light saturation, and additional $P P F$ is not used efficiently, causing a gradual drop in LUE $_{\text {net }}$. Net LUE per unit leaf area was similar in all DLI treatments at $P P F$ levels $>200 \mu \mathrm{mol} \cdot \mathrm{m}^{-2} \cdot \mathrm{s}^{-1}$. At $P P F$ levels $>50 \mu \mathrm{mol} \cdot \mathrm{m}^{-2 \cdot} \mathrm{s}^{-1}, \mathrm{LUE}_{\text {net }}$ per unit ground area increased with increasing DLI, likely because of increased light capture.

\section{Conclusions}

Wax begonias acclimated to varying DLI levels. Under conditions of high DLI, wax begonias increased their $\mathrm{P}_{\mathrm{g}, \max }$, enabling them to fix more carbon under high $P P F$ conditions. Increased $\mathrm{P}_{g, \max }$ under high DLI did not cause changes in the LSP of wax begonias. Under conditions of low DLI, wax begonias increased their leaf chlorophyll concentration, thereby more efficiently 
absorbing light and optimizing carbon gain under low PPF conditions. Our results indicated that responses seen at whole-plant level were different from those seen at leaf level. When corrected for differences in leaf area among DLI treatments, $\alpha$ and LCP of wax begonias was not affected by the DLI, however, both of them increased for whole-plants. This study shows that one of the potential limitations to rapid growth of wax begonias is their low LSP, because wax begonias were unable to utilize light levels above $530 \mu \mathrm{mol} \cdot \mathrm{m}^{-2} \cdot \mathrm{s}^{-1}$. This may explain the low photosynthesis and growth rates in wax begonias.

\section{Literature Cited}

Adams, W.W. III. and B. Demmig-Adams. 1992. Operation of xanthophyll cycle in higher plants in response to diurnal changes in incident sunlight. Planta 186:390-398.

Allard, G., C.J. Nelson, and S.G. Pallardy. 1991. Shade effects on growth of tall fescue: I. Leaf anatomy and dry matter partitioning. Crop Sci. 31:163-167.

Amthor, J.S. 1989. Respiration and crop productivity. Springer-Verlag, New York.

Baille, M., R. Romerio-Aranda, and A. Baille. 1996. Gas-exchange responses of rose plants to $\mathrm{CO}_{2}$ enrichment and light. J. Hort. Sci. 71:945-956.

Callan, E.J. and C.W. Kennedy. 1995. Intercropping stokes aster: Effect of shade on photosynthesis and plant morphology. Crop Sci. 35:1110-1115.

Casella, E and R. Ceulemans. 2002. Spatial distribution of leaf morphological and physiological characteristics in relation to local radiation regime within the canopies of 3-year old Populus clones in coppice culture. Tree Physiol. 22:1277-1288.

Close, D.C., C.L. Beadle, and M.J. Hovenden. 2001. Cold-induced photoinhibition and foliar pigment dynamics of Eucalyptus nitens seedlings during establishment. Aust. J. Plant Physiol. 28:1133-1141.

Evans, J.R. and H. Poorter. 2001. Photosynthesis acclimation of plants to growth irradiance: The relative importance of specific leaf area and nitrogen partitioning in maximizing carbon gain. Plant, Cell Environ. 24:755-767

Funnell, K.A., E.W. Hewett, J.A. Plummer, and I.J. Warrington. 2002. Acclimation of photosynthetic activity of Zantedeschia 'Best Gold' in response to temperature and photosynthetic photon flux. J. Amer. Soc. Hort. Sci. 127:290-296.

Giaglaras, P., M. Baille, and A. Baille. 1995. Net photosynthesis response to light and air $\mathrm{CO}_{2}$ concentration of Begonia x heimalis: Whole plant measurements and modelling. Scientia Hort. 63:83-100.

Lambers, H., F.S. Chapin III, and T.L. Pons. 1998. Photosynthesis, respiration, and long distance transport, p. 34. In: Plant physiological ecology, Springer-Verlag, New York.

Leonardos, E.D., M.J. Tsujita, and B. Grodzinski. 1994. Net carbon dioxide exchange rates and predicted growth patterns in Alstroemeria
'Jacqueline' at varying irradiances, carbon dioxide concentrations, and air temperature. J. Amer. Soc. Hort. Sci. 119:1265-1275.

Luo, Y., D. Hui., W. Cheng., J.S. Coleman., D.W. Johnson, and D.A. Sims. 2000. Canopy quantum yield in a mesocosm study. Agr. For. Meteorol. 100:35-48.

Marenco, R.A., J.F.C. Gonglaves, and G. Vieira. 2001. Leaf gas exchange and carbohydrates in tropical trees differing in successional status in two light environments in central amazonia. Tree Physiol. 21:1311-1318.

Miller, A.M., M.W. van Iersel, and A.M. Armitage. 2001. Whole-plant carbon dioxide exchange responses of Angelonia angustifolia to temperature and irradiance. J. Amer. Soc. Hort. Sci. 125:606-610.

Nemali, K.S and M.W. van Iersel. 2004. Light effects on wax begonia: Photosynthesis, growth respiration, maintenance respiration and carbon use efficiency. J. Amer. Soc. Hort. Sci. 129:416-424.'

Norcini, J.G., G.W. Knox, and P.C. Andersen. 1991. Leaf gas exchange of eastern redbud (Cercis canadensis L.) grown under sun and shade. J. Environ. Hort. 9:215-218.

Oguchi, R., K. Hikosaka, and T. Hirose. 2003. Does the photosynthetic light acclimation need change in leaf anatomy? Plant, Cell Environ. 26:505-512.

Parry, M.A.J., P.J. Andralojc, R.A.C. Mitchell, P.J. Madgwick, and A.J. Keys. 2003. Manipulation of Rubisco: The amount, activity, function and regulation. J. Expt. Bot. 54:1321-1333.

Piel, C., E. Frank., X. Le Roux, and B. Gentry. 2002. Effects of local irradiance on $\mathrm{CO}_{2}$ transfer conductance of mesophyll in walnut. J. Expt. Bot. 53:2423-2430.

Reich, P.B., I.J. Wright, J. Cavender-Bares, J.M. Craines, J. Oleksyn, M. Westoby, and M.B. Walters. 2003. The evolution of plant functional variation: Traits, spectra, and strategies. Intl. J. Plant Sci. 164: 143-164.

Rosati, A., G. Esparza, T.M. DeJong, and R.W. Pearcy. 1999. Influence of canopy light environment and nitrogen availability on leaf photosynthetic characteristics and photosynthetic nitrogen-use efficiency of field-grown nectarine trees. Tree Physiol. 19:173-180.

Seemann, J.R. 1989. Light adaptation/acclimation of photosynthesis and the regulation of ribulose-1,5-bisphosphate carboxylase activity in sun and shade plants. Plant Physiol. 91:379-386.

Thornley, J.H.M. 1998. Dynamic model of leaf photosynthesis with acclimation to light and nitrogen. Ann. Bot. 81:421-430.

van Iersel, M.W. and B. Bugbee. 2000. A multiple chamber, semicontinuous, crop carbon dioxide exchange system: Design, calibration, and data interpretation. J. Amer. Soc. Hort. Sci. 125:86-92.

von Caemmerer, S and G.D. Farquhar. 1981. Some relationships between the biochemistry of photosynthesis and the gas exchange of leaves. Planta 153:376-387.

USDA-NASS. 2003. Floriculture crops 2002 summary. U.S. Dept. Agr., Washington, D.C.

Warren, C.R. and M.A. Adams. 2001. Distribution of N, Rubisco and photosynthesis in Pinus pinaster and acclimation to light. Plant, Cell Environ. 24:597-609. 